\title{
Quantitative Measurement of p21 Protein in Human Serum by Time-Resolved Fluoroimmunoassay
}

\author{
Guilan WANG, ${ }^{* 1}$ Jingli YUAN, ${ }^{* 1}$ Kazuko Matsumoto, ${ }^{* 2, * 3 \dagger}$ and Hiroko KIMURA ${ }^{* 3, * 4}$ \\ *1 Department of Analytical Chemistry, Dalian Institute of Chemical Physics, Chinese Academy of Sciences, \\ Dalian 116012, P. R. China \\ *2 Department of Chemistry, Advanced Research Center for Science and Engineering, Waseda University, \\ Shinjuku, Tokyo 169-8555, Japan \\ *3 Japan Science and Technology Corporation (JST), Kawaguchi, Saitama 332-0012, Japan \\ *4 Department of Forensic Medicine, Juntendo University School of Medicine, Bunkyo, Tokyo 113-8421, Japan
}

(Received January 21, 2001; Accepted April 25, 2001)

The p21 protein (a non-ras $21 \mathrm{kDa}$ protein) binds to cyclindependent kinases and is an inhibitor of the kinases in mammalian cells. ${ }^{1-4}$ It can be transcriptionally activated by wild-type $\mathrm{p} 53$, but not by mutant $\mathrm{p} 53,{ }^{2}$ and functions to block cell-cycle progression in many human neoplasms..$^{5}$ It has been reported that human $\mathrm{p} 21$ protein is related to many human tumors, such as urogenital cancer ${ }^{6-8}$ and lung cancer. ${ }^{9}$ Although an enzyme-linked immunosorbent assay (ELISA) method has been established for the measurement of p21 protein in human sera ${ }^{7,8}$ the method is only semi-quantitative. Serum samples were first coated on the wells of a microtiter plate, and then the rabbit anti-p21 antibody, biotinylated goat anti-rabbit $\operatorname{IgG}$ antibody, and peroxidase-labeled avidin were added. ${ }^{8}$

Time-resolved fluoroimmunoassay (TR-FIA) using an europium chelate as the label is an established immunoassay method, and has been widely used for bioassays. ${ }^{10-17}$ Recently we synthesized a new tetradentate $\beta$-diketonate-Eu ${ }^{3+}$ fluorescence chelate, 4,4'-bis(1" $1^{\prime \prime}, 1^{\prime \prime}, 2^{\prime \prime}, 2^{\prime \prime}, 3^{\prime \prime}, 3^{\prime \prime}$-heptafluoro4",6"-hexanedion-6"-yl)-chlorosulfo-o-terphenyl (BHHCT)$\mathrm{Eu}^{3+}$, and characterized its application for highly sensitive TRFIA. ${ }^{18}$ The BHHCT-Eu ${ }^{3+}$-labeled antibody, streptavidin (SA), SA-BSA conjugate (BSA is bovine serum albumin), and drugBSA conjugate have been used for the highly sensitive measurement of tumor markers, ${ }^{18,19}$ immunoglobulin, ${ }^{20}$ hormone ${ }^{21}$ and drugs. ${ }^{22,23}$

In the present study, we developed a novel quantitative measurement method of p21 protein in human sera. The method is competitive-type immunoassay, in which biotinylated p21-BSA conjugate and BHHCT-Eu ${ }^{3+}$-labeled SA-BSA are used. The assay was carried out on a 96-well microtiter plate coated with rabbit anti-goat IgG antibody. After a goat antihuman p21 antibody was reacted in the wells, the competitive reaction of biotinylated p21-BSA and p21 standard solutions (or serum samples) with goat anti-human p21 antibody was performed. Finally BHHCT-Eu ${ }^{3+}$-labeled SA-BSA was added to each well to react with the biotinylated p21-BSA, and solidphase time-resolved fluorescence measurements were carried out. The method gives the detection limit of $1.07 \mathrm{ng} / \mathrm{ml}$ and the

† To whom correspondence should be addressed.

E-mail: kmatsu@mn.waseda.ac.jp large dynamic range up to $c a .2000 \mathrm{ng} / \mathrm{ml}$ for human p21 protein. The intra-assay coefficient of variation (RSD) and the recovery are approximately in the range of $2-8 \%$ and $85-$ $110 \%$, respectively, for the human serum samples.

\section{Experimental}

\section{Apparatus and materials}

The 96-well microtiter plates (Fluoro Nunc Modules) were used. Time-resolved fluorometric measurements were carried out on a DELFIA 1234 fluorometer (Wallac) under these measurement conditions: excitation wavelength, $340 \mathrm{~nm}$; emission wavelength, $615 \mathrm{~nm}$; delay time, $0.2 \mathrm{~ms}$; window time, $0.4 \mathrm{~ms}$; and cycling time, $1.0 \mathrm{~ms}$. A human $\mathrm{p} 21$ protein (control peptide) and a goat anti-human p21 (N-20) polyclonal antibody (affinity-purified IgG, reacts with p21 of human origin by Western blotting and immunohistochemistry, and not crossreactive with $\mathrm{p} 27$ or other mitotic inhibitors) were purchased from Santa Cruz Biotechnology, Inc. The p21 standard solutions were prepared by diluting p21 control peptide with $0.05 \mathrm{M}$ Tris- $\mathrm{HCl}$ buffer of $\mathrm{pH} 7.8$ containing 5\% BSA, $0.1 \%$ $\mathrm{NaN}_{3}$, and $0.9 \% \mathrm{NaCl}$. A rabbit anti-goat $\mathrm{IgG}$ antibody was purchased from Bethyl Laboratories, Inc. Human serum samples were collected from healthy people and were stored at $-20^{\circ} \mathrm{C}$ before use.

\section{Preparation of the biotinylated p21-BSA conjugate}

The preparation basically followed the biotinylation procedure for the methamphetamine-BSA conjugate..$^{22}$ After repeated dialysis of $1.0 \mathrm{ml}$ of $\mathrm{p} 21$ protein $(100 \mu \mathrm{g} / \mathrm{ml})$ at $4^{\circ} \mathrm{C}$ against 31 of saline, $1.0 \mathrm{ml}$ of $0.1 \mathrm{M}$ phosphate buffer of $\mathrm{pH} 7.0$ containing $0.5 \mathrm{mg}$ of BSA was added to the solution. While stirring, 0.1 $\mathrm{ml}$ of $1.0 \%$ glutaraldehyde was added. The solution was stirred at room temperature for $1 \mathrm{~h}$, and further incubated at $4^{\circ} \mathrm{C}$ for 24 h. To the solution was added $2 \mathrm{mg}$ of $\mathrm{NaBH}_{4}$, and the solution was stirred at room temperature for $2 \mathrm{~h}$. The solution was dialyzed twice each for $24 \mathrm{~h}$ against 31 of saline at $4^{\circ} \mathrm{C}$ and then diluted to $3.0 \mathrm{ml}$ with water, to which $25 \mathrm{mg}$ of $\mathrm{NaHCO}_{3}$ and 4 $\mathrm{mg}$ of sulfosuccinimidyl-6-(biotin-amido)hexanoate (NHS-LCbiotin, Pierce Chemical Co.) were added. After the solution 


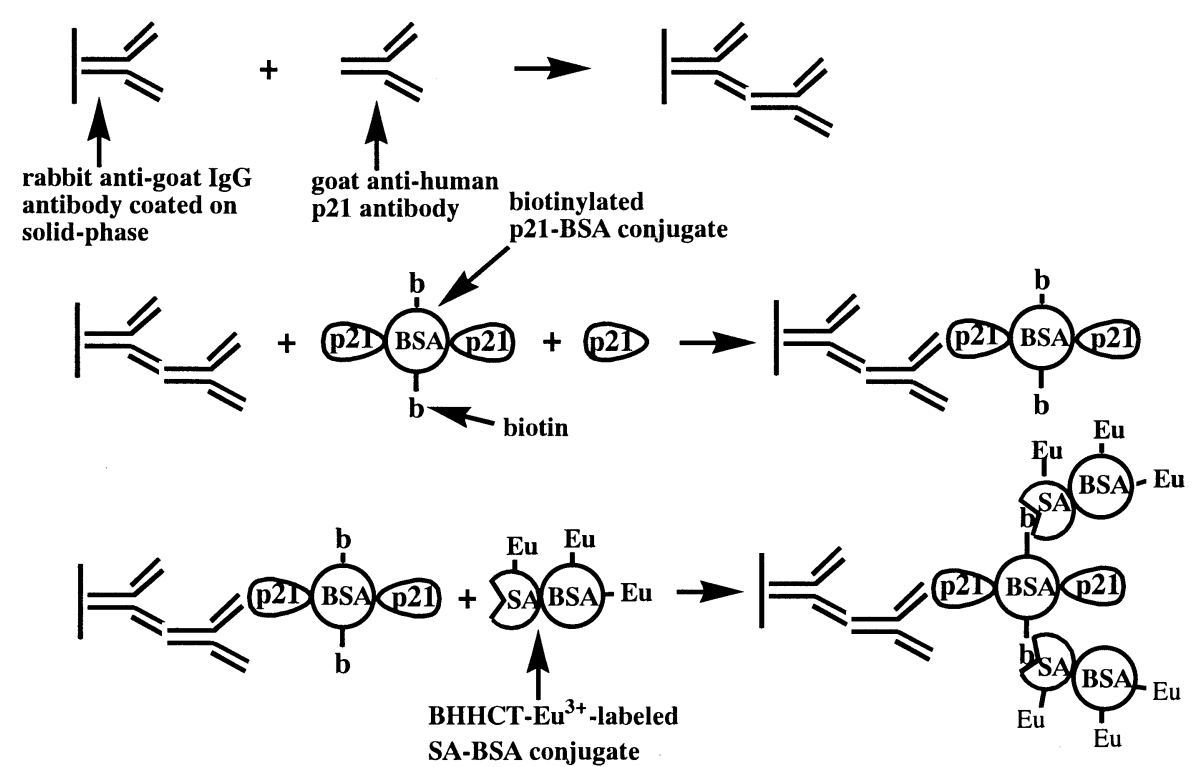

Fig. 1 Schematic representation of the immunoassay for $\mathrm{p} 21$ protein in human sera.

was stirred at room temperature for $1 \mathrm{~h}$ and further incubated at $4^{\circ} \mathrm{C}$ for $24 \mathrm{~h}$, it was dialyzed twice at $4^{\circ} \mathrm{C}$ against 31 of $0.1 \mathrm{M}$ $\mathrm{NaHCO}_{3}$ containing $0.25 \mathrm{~g}$ of $\mathrm{NaN}_{3}$, each time for $24 \mathrm{~h}$. The biotinylated $\mathrm{p} 21-\mathrm{BSA}$ conjugate solution was stored at $-20^{\circ} \mathrm{C}$. When it was used in immunoassay, the solution was diluted 400-fold with $0.05 \mathrm{M}$ Tris- $\mathrm{HCl}$ buffer of $\mathrm{pH} 7.8$ containing $0.2 \% \mathrm{BSA}, 0.1 \% \mathrm{NaN}_{3}$, and $0.9 \% \mathrm{NaCl}$.

Preparation and labeling of the SA-BSA conjugate with BHHCT Preparation and labeling of the SA-BSA conjugate, $\mathrm{SA}(\mathrm{BSA})_{0.9}(\mathrm{BHHCT})_{46}$, were described in the previous report. ${ }^{20}$ It was diluted 700 -fold with $0.05 \mathrm{M}$ Tris- $\mathrm{HCl}$ buffer of $\mathrm{pH} 7.8$ containing $1.0 \times 10^{-7} \mathrm{M} \mathrm{EuCl}_{3}, 0.2 \% \mathrm{BSA}, 0.1 \% \mathrm{NaN}_{3}$, and $0.9 \% \mathrm{NaCl}$ and was heated at $56^{\circ} \mathrm{C}$ for $2 \mathrm{~h}$ before use in immunoassay.

\section{Immunoassay of human $\mathrm{p} 21$}

One hundred microliters of $0.1 \mathrm{M}$ carbonate buffer of $\mathrm{pH} 9.6$ containing $15 \mu \mathrm{g} / \mathrm{ml}$ of rabbit anti-goat $\operatorname{IgG}$ antibody were incubated in a 96-well microtiter plate for $24 \mathrm{~h}$ at $4^{\circ} \mathrm{C}$. The wells were rinsed twice with $0.05 \mathrm{M}$ Tris- $\mathrm{HCl}$ buffer of $\mathrm{pH} 7.8$ containing $0.05 \%$ Tween 20 (buffer 1) and once with $0.05 \mathrm{M}$ Tris-HCl buffer of pH 7.8 (buffer 2). To each well was added $50 \mu \mathrm{l}$ of $0.05 \mathrm{M}$ Tris- $\mathrm{HCl}$ buffer of $\mathrm{pH} 7.8$ containing $6 \mu \mathrm{g} / \mathrm{ml}$ of goat anti-human p21 antibody, $0.2 \%$ BSA, $0.1 \% \mathrm{NaN}_{3}$, and $0.9 \% \mathrm{NaCl}$. The plate was incubated for $24 \mathrm{~h}$ at $4{ }^{\circ} \mathrm{C}$, and rinsed twice with buffer 1 and once with buffer 2 . After $50 \mu$ of 1:1 mixed solutions of biotinylated p21-BSA and p21 standard solutions (or human serum samples) were incubated at $37^{\circ} \mathrm{C}$ for $2 \mathrm{~h}$ in the wells, the wells were rinsed twice with buffer 1 and once with buffer 2 . To each well was added $50 \mu$ l of the $\mathrm{SA}(\mathrm{BSA})_{0.9}(\mathrm{BHHCT})_{46}-\mathrm{Eu}^{3+}$ solution. After incubation at $37^{\circ} \mathrm{C}$ for $1 \mathrm{~h}$, the wells were rinsed 4 times with $0.05 \mathrm{M}$ Tris- $\mathrm{HCl}$ buffer of $\mathrm{pH} 9.1$ containing $0.05 \%$ Tween 20 , and subjected to solid-phase time-resolved fluorometric measurement.

\section{Results and Discussion}

Evaluation of the immunoassay method

The immunoassay procedure of the present method is shown

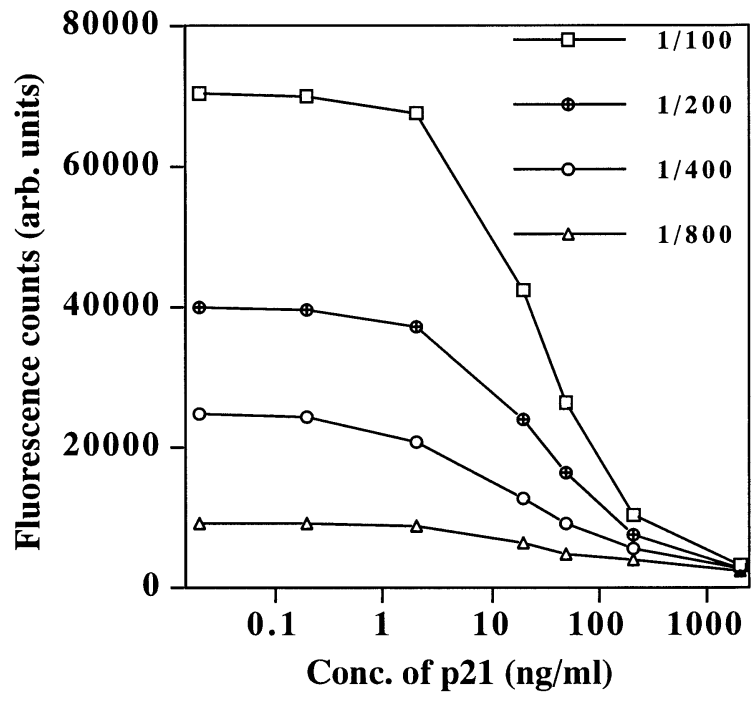

Fig. 2 The influence of biotinylated p21-BSA concentration on the fluorescence intensity in the measurement of p21 protein. The concentrations are expressed on the dilution factors in the figure.

in Fig. 1. In the method, a secondary antibody (rabbit anti-goat IgG antibody) was used for the well coating, and the biotinylated p21-BSA conjugate was used for the competitive reaction. The present method is complicated compared with the method in which goat anti-human p21 antibody is coated on the wells directly; it was found that the goat anti-human p21 antibody used in this assay can not be effectively coated on the wells by the general physical absorption method. By using the present method, the goat anti-human p21 antibody was immobilized on the solid-phase successfully. We also tested the use of a biotinylated $\mathrm{p} 21$ protein for the competitive reaction; however, a significant signal could not be obtained. This fact indicates that the direct biotinylation of p21 with NHS-LCbiotin was not effective, or that the binding activity of p21 with anti-p21 antibody was lost after the biotinylation. We have reported that a methamphetamine-BSA conjugate can be easily biotinylated by using the same reaction, ${ }^{22}$ since a BSA molecule 


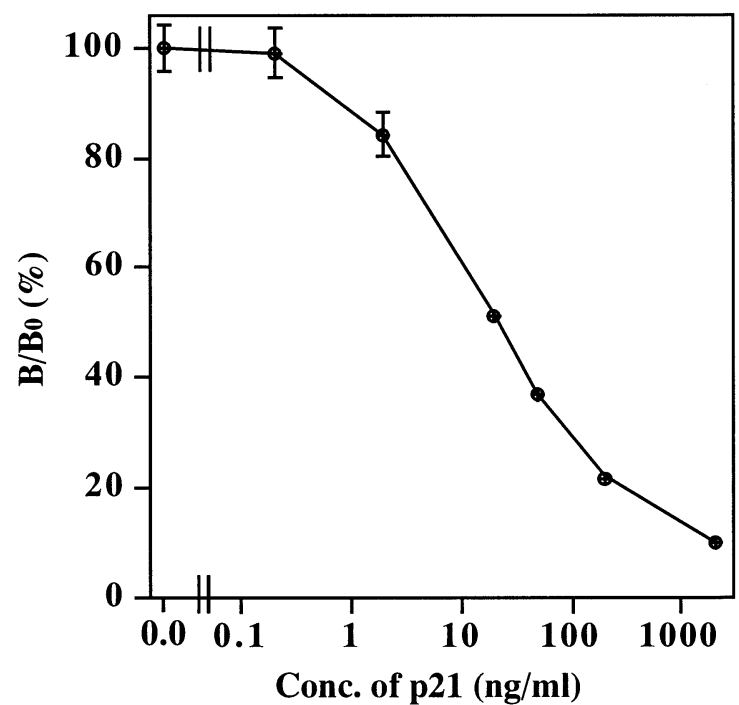

Fig. 3 The calibration curve for human p21 protein.

has 59 amino groups, ${ }^{24}$ some of which are used for binding to a drug molecule but others still remain unbound, and can be used for binding to biotin. By using this method, the biotinylated p21-BSA was prepared and the immunoassay using it gave successful results. The effect of biotinylated p21-BSA concentration $(1 / 100,1 / 200,1 / 400$ and $1 / 800$ dilution) on the competitive reaction was examined. The results, as shown in Fig. 2, indicate that the concentration of $1 / 400$ dilution is optimal, since the slope of the calibration curve still continues going down only with the dilution factor to $0.2 \mathrm{ng} / \mathrm{ml}$ of $\mathrm{p} 21$.

Quantitative measurement of p21 in human serum samples

The calibration curve of human p21 protein is shown in Fig. 3. The detection limit, defined as the concentration corresponding to twice the standard deviation of the background signal, is 1.07 $\mathrm{ng} / \mathrm{ml}$, which is low enough for the assay of $\mathrm{p} 21$ protein in human sera. ${ }^{8}$ The method also gives a large dynamic range of 1 to $2000 \mathrm{ng} / \mathrm{ml}$.

The precision and recovery of $\mathrm{p} 21$ protein added to human serum samples are shown in Table 1 . The results of $2-8 \%$ RSD for $n=6$ (the standard deviation was calculated with $n-1$ ) and $85-110 \%$ recovery show that the present method can be employed for the general clinical analysis of p21 protein in human sera with good accuracy and precision. In addition, the present method can also be used for the analysis of $\mathrm{p} 21$ protein normal human tissues and various tumor tissues.

\section{Acknowledgements}

The present work has been supported by CREST (Core Research for Evolutional Science and Technology) of Japan Science and Technology Corporation (JST), and Grant-in-Aid for COE Research, Ministry of Education, Culture, Sports, Science and Technology (MEXT).

\section{References}

1. J. W. Harper, G. R. Adami, N. Wei, K. Keyomars, and S. J. Elledge, Cell, 1993, 75, 805.

2. W. S. El-Deiry, T. Tokino, V. E. Velculescu, D. B. Levy,
Table 1 Analytical precision and recovery of p21 protein added to serum samples (serum A and serum B)

\begin{tabular}{cccc}
\hline Added $/ \mathrm{ng} \mathrm{m}^{-1}$ & ${\text { Found } / \mathrm{ng} \mathrm{ml}^{-1}}$ & $\mathrm{RSD}, \%(n=6)$ & Recovery, \% \\
\hline (Serum A) & 5.10 & 4.25 & - \\
50.0 & 48.3 & 7.20 & 86.4 \\
20.0 & 24.5 & 4.13 & 97.0 \\
5.00 & 9.67 & 5.25 & 91.4 \\
$($ Serum B) & 4.12 & 6.31 & - \\
50.0 & 49.4 & 2.10 & 90.6 \\
20.0 & 24.7 & 7.87 & 102.9 \\
5.00 & 9.57 & 3.65 & 109.0 \\
\hline
\end{tabular}

R. Parsons, J. M. Trent, D. Lin, W. E. Mercer, K. W. Kinzier, and B. Vogelstein, Cell, 1993, 75, 817.

3. Y. Xiong, G. J. Hannon, H. Zhang, D. Casso, R. Kobayashi, and D. Beach, Nature, 1993, 366, 701.

4. W. S. El-Deiry, J. W. Harper, P. M. O'Connor, V. E. Velculescu, C. E. Canman, J. Jackman, J. A. Pietenpol, M. Burrell, D. E. Hill, Y. Wang, K. G. Wiman, W. E. Mercer, M. B. Kastan, K. W. Kohn, S. J. Elledge, K. W. Kinazler, and B. Vogelstein, Cancer Res., 1994, 54, 1169.

5. H. Khalid, N. Yagi, T. Hiura, and S. Shibata, Brain Tumor Pathol., 1998, 15, 89.

6. C. Shalitin, R. Epelbaum, C. Valansi, R. Segal, T. Mekori, B. Lover, and E. Robinson, Int. J. Cancer, 1991, 49, 861.

7. C. Shalitin, R. Epelbaum, B. Moskovitz, R. Segal, C. Valansi, T. Mekori, and M. Lerner, Int. J. Oncol., 1992, 1, 107.

8. E. Grundner-Culemann, C. Bokemeyer, V. Neubauer, C. Shalitin, H. J. Schmoll, H. Poliwoda, and T. Benter, J. Cancer Res. Clin. Oncol., 1993, 119, 685.

9. M. Caputi, V. Esposito, A. Baldi, A De Luca, C. Dean, G. Signoriello, F. Baldi, and A. Giordano, Am. J. Respir. Cell Mol. Biol., 1998, 18, 213.

10. I. Hemmilä, Clin. Chem., 1985, 31, 359.

11. E. Soini and T. Lögren, CRC Crit. Rev. Anal. Chem., 1987, 18,105

12. E. P. Diamandis, Clin. Biochem., 1988, 21, 139.

13. E. P. Diamandis and T. K. Christopoulos, Anal. Chem., 1990, 62, 1149A

14. E. F. G. Dickson, A. Pollak, and E. P. Diamandis, Pharmac. Ther., 1995, 66, 207.

15. I. Hemmilä, J. Alloys Comp., 1995, 225, 480.

16. M. Elbanowski and B. Makowska, J. Photochem. Photobiol. A: Chem., 1996, 99, 85.

17. J. Yuan and K. Matsumoto, Bunseki Kagaku, 1999, 48, 1077.

18. J. Yuan, K. Matsumoto, and H. Kimura, Anal. Chem., 1998, 70, 596.

19. K. Matsumoto, J. Yuan, G. Wang, and H. Kimura, Anal. Biochem., 1999, 276, 81.

20. J. Yuan, G. Wang, H. Kimura, and K. Matsumoto, Anal. Biochem., 1997, 254, 283.

21. J. Yuan, G. Wang, H. Kimura, and K. Matsumoto, Anal. Sci., 1998, 14, 421.

22. H. Kimura, J. Yuan, G. Wang, K. Matsumoto, and M. Mukaida, J. Anal. Toxicol., 1999, 23, 11.

23. J. Yuan, G. Wang, H. Kimura, and K. Matsumoto, Anal. Sci., 1999, 15, 125.

24. R. A. Evangelista, A. Pollak, B. Allore, E. P. Templeton, R. C. Morton, and E. P. Diamandis, Clin. Biochem., 1988, 21 , 173. 